\title{
THE EFFECT OF PICTURE AND PICTURE ON STUDENTS' ACHIEVEMENT IN WRITING DESCRIPTIVE TEXT
}

\author{
Joshua Marthin Simbolon ${ }^{1}$, Sri Dayanti Bu'ulolo², and \\ Anisyah Nur Salfiah ${ }^{3}$ \\ josimbolon97@gmail.com ${ }^{1}$ \\ dayantibuulolo@gmail.com ${ }^{2}$ \\ annisanursalfiah@gmail.com ${ }^{3}$
}

\section{Universitas Prima Indonesia}

\begin{abstract}
This study aims to determine whether the picture and picture method has a significant effect on the text description writing skills of students at SMP AlHidayah Medan or not. This study used quantitative method. The results of this study were obtained from the $t$ test with a significance level of $\alpha=0.05$ and the accumulated results of two different groups, namely the experimental group (which applied picture and picture) and the control group (which did not use picture and picture). In the pre-test experimental group the average result obtained was 51.15 while the average post-test result was 83.75. In the pre-test control group the average result obtained was 53.45, while the average post-test result was 79.65. The results of the hypothesis obtained are ttest $=2.831 \geq$ ttable $=$ 1.685. This proves that the value of the experimental group is better than the control group, so it can be concluded that the use of pictures and picture methods can have a significant impact on students' descriptive writing skills.
\end{abstract}

\section{Keywords: Writing skills, Effect, Picture and Picture, Description Text}

\section{INTRODUCTION}

English is used as an international language which is needed by many people. There are four skills in English, namely writing, reading, speaking, and listening. The activity used to express ideas or experiences in paragraphs can be called writing. Writing is considered a fairly complicated skill because writing skills involved the ways of writing texts or essays where students are expected to know how to make good sentences, compose texts, and express ideas that come from their thoughts in accordance with good and correct English structures. According to Richards \&Renandya (2002: 303), writing is the most difficult skill to master because of the difficulty of generating, organizing, and translating ideas into 
readable text. Due to the complexity of its writing skills, teachers are required to teach students on how to write correctly.

According to Pranoto (2004: 9) writing means putting the thoughts into writing or telling something to others through writing. Writing can also be interpreted as an expression or expression of feelings that are expressed in written form. There are several types of writing in English learning, namely descriptive, narrative, argumentative, recount, and others. Where narrative text is imaginary text, true stories and fairy tales that aim to entertain the readers. Argumentative text is the text that contains opinions and accompanied by examples and evidence that aims to convince the readers.

\section{THEORETICAL FRAMEWORKS}

Report text is a text that aims to convey information to readers about something as it is as a result of a study. Texts designed to inform readers of past events are called recount texts. This research focuses on descriptive text. Descriptive writing is one of the writing skills in English which is a comprehensive description of words through writing and also aims to make the reader understand the writing and even feel the atmosphere, trying to describe it as if it is in front of the reader or in other words to animate the object to the reader. In this type of text, students are required to list the characteristics of something and it is usually related to the physical appearance of the object described (Smalley et. At., 2001).

A skill that requires special attention is to write the descriptive writing. The skill requires students to help readers to think about what they have written, such as able to create a mental or imagine about moments, characters, things, places, and memories (Soejatmiko and Taloko 2003:266). In the current pandemic situation, learning is very difficult to do directly. Therefore,the alternative online media is very helpful in teaching and learning activities. Teachers can continue to carry out the usual teaching and learning system such as using the WhatsApp application for classes or via zoom. In order to create the interest and effectiveness in teaching descriptive text, teachers are expected to use the interesting methods. Therefore, the picture and picture method is the best solution that can be used by teachers to teach how to write good and correct descriptive text in an interesting way.

Basically, students are expected to be able to write the descriptive text properly and correctly, but in reality students are still not able to write the descriptive text and it can be seen from the average score of students in writing the descriptive text. Based on the author's experience in the practice of teaching in SMP Al-Hidayah Medan, many students still don't know how to write descriptive text correctly and do not know how to choose a vocabulary appropriate. For inclusion, the average ability in writing the descriptive texts is $50 \%$ based on their scores in semester two on the seventh grade. Many students find that it is difficult to write the descriptive text because they do not know what to write and describe, 
students find it difficult to write the capital letters properly, find it difficult to choose the right vocabulary, and it is difficult to understand the general structure of descriptive text. Therefore, to overcome this problem it is very important for teachers to find the right media and to support the students to write the descriptive texts.

The media is needed in the teaching to attract students' interest in writing and can streamline the teaching and learning process. Pictures and picture learning models are a form of cooperative learning. Pictures and picture learning models are positive, innovative, creative and interesting (Frisca 2013:34). (Soejatmiko and Taloko, 2003) (Dewi, 2013) There are many types of learning media that can be used in the teaching and learning process and the writer choose one of them, namely pictures. The use of picture as a visual medium in the teaching and learning process is expected to help to solve the problems in writing descriptive text so the quality of learning outcomes can be better. Teachers can use pictures to motivate students to write and stimulate and guide students to write descriptive text, especially when teaching through online media, which usually when learning through onlinemost students get bored faster. Here students will use pictures that are related to the material being studied, therefore the picture media can be a guide for students to be able to start writing and pouring their ideas into written form. Therefore, in this study the authors are interested in examining whether the picture and picture method can affect students' abilities in writing descriptive texts.

In this study the authors took two previous studies to strengthen this research. There are two previous researchers who have the same topic as this researcher. The first researcher is Fitriani, Sofia Winda Nur (2009: 73). Based on the author's findings, the authors conclude that teaching descriptive writing is beneficial for students and teachers. This can be seen from the post-test results that the highest student achievement of the five writing items is content (88.64).

The second researcher is Sa'diyah (2011), picture can boost student concern. Picture also enhance student encouragement and cooperation during learning activities. Picture can also be used an interesting lesson to increase student encouragement. Picture is a medium learning. Picture can be used as guidelines in writing activities (Sadiman, 2005) in Siahaan (2013).

This research will be conducted to find out a good influence as the effect on student achievement in writing descriptive texts and also attracting students to be more interested in writing by using the picture and picture media. Through these activities, students will get the opportunity to write descriptive texts using pictures and pictures media. To collect data and answer research questions, researchers used writing tests in this study.

\section{METHOD}


This study will determine the effect of the picture and picture method in writing descriptive text on students. In conducting this thesis, the research design is a case study in the form of a quantitative research design. There are two classes, experimental group and control group. Experimental will be taught by using picture and picture method, while the control group will be taught by conventional technique. Kasiram (2008: 149) defines quantitative research is a process of finding knowledge that uses data in the form of numbers as a means of analyzing information about what you want to know. It is called a quantitative method because the theories provided and the data collected are more quantitative. The investigation was carried out at SMP Al-Hidayah which is located in Jl. Starban GG. Sahabat.

\section{Population and Sample}

Population is defined as all class members, events, or class objects that are well-defined (Ary, 2010: 148). The population of this research will be held at the eight grade students of SMP Al-Hidayah Medan. The total population is 40 students which are divided into two classes, VIII-A and VIII-B .

Based on Trianto (2010: 256) the sample is part or representative of the population under study. The samples are VIII-A class and VIII-B class. Class VIII-A as the experimental group which is taught by using pictures will consisted of 20 students while the class VIII-B as the control group will be taught without by using pictures and will be consist of 20 students.

\section{Instrument for Collecting Data}

To collect data in research and to measure students' abilities, the instruments will be divided into two test namely pretest at the first meeting and post-test at the last meeting. The test will be administered to the students in both experimental and control group.

The instrument of this test will be the essay test. The test will be given to experimental group and control group. The participants will be ask to create a descriptive text as for subject such as the thing, place or a person. The picture and picture method will be applied in experimental class, whereas researchers will follow method without pictures or method that have been applied by teachers in schools for the control class.

\section{The Procedure of Research \\ Pre-test}

Pre-test is used to know the ability of students in writing descriptive texts before treatment is given. The pre-test will be given at the beginning of the class on experimental and control class. The classes will be asked to write a descriptive text based on the topic given by the researcher.

\section{Treatment}

After the pre-test, the experimental group will be taught by using pictures, while the control group will be taught without using picture and only assisted by 
using explanations. Both of the classes will be taught in the same topic and material.

\section{Post-test}

After the treatment has been completed, the researcher will give a post-test in the last session. This test will be given to get the mean scores as the effect for the experimental group and control group. The test for post test will be same as the pre test. The objective is to measure off the students' writing ability after they taught by using the picture and picture method on the treatment session.

\section{Scoring of the Test}

In analyzing the assessment on the student test paper in writing the descriptive text, the writer will use several conditions of writing, they are namely: content, organization, vocabulary, the language used, and mechanics which presented by Jacob et al in Reyhan (2012:3). For the addition, the score for the aspects are: the content is 30 points, the language used is 25 points, the organization and vocabulary are 20 points for each, and last for the mechanics is 5 points.

\section{Technique of Analysis Data}

Researchers collect student assignments both using pictures and without pictures obtained from the pre and post tests, then the researcher will give a score for each assignment and compare them using the $t$ test. In this study, the formula " $t$ " test is used to see the contrats of the average value the pre test and post test in determining the acceptable hypothesis and to measure whether the instrument under treatment can have an influence on students' writing skill or not. In conducting pre-experimental analysis, a hypothesis is needed to know whether there is a significant contrats after the activity is completed.

\section{FINDINGS AND DISCUSSION}

The researchers showed the data analysis data description that is calculated from sample data. Data were obtained from the control class an experimental class in SMP Al-Hidayah Medan. The researchers conducted an investigation using a pretest to determine the descriptive test of the students and assessed the students using a posttest to determine the writing skills of the students in a descriptive text after receiving treatment in the experimental class. It was applied using the method of pictures and images to help students affect their writing, especially in descriptive text. The researcher then used the t test to find out whether or not the students' ability to write descriptive texts is affected by the hypothesis. The data will be shown below:

The Description of Data

Score of Pre test and Post Test Control Class 
Table 3.1 Pre and Post Test Scores for Control Class

\begin{tabular}{|l|l|l|l|}
\hline No & Name & Pre - test $\left(\mathrm{Y}_{1}\right)$ & Post test $\left(\mathrm{Y}_{2}\right)$ \\
\hline 1 & ADEK KURNIAWAN & 39 & 65 \\
\hline 2 & ADEN AZI ANUGRAH & 44 & 70 \\
\hline 3 & AIDIL PRASETYA & 37 & 66 \\
\hline 4 & AIRIL RAMADANI & 68 & 80 \\
\hline 5 & DAMAL RIVALDO & 52 & 78 \\
\hline 6 & FASYA AYU AZZAHRA & 65 & 93 \\
\hline 7 & FABIAN ANURAGA & 45 & 80 \\
& AKMAL & & \\
\hline 8 & FAYYAZA ALFAZILA & 56 & 81 \\
\hline 9 & GILANG ANGGA KUSUMA & 59 & 97 \\
\hline 10 & IDRIS AFFANDI & 53 & 78 \\
\hline 11 & M. ABDULLAH ZOHIR & 62 & 83 \\
\hline 12 & MAGHFIROH NABILA & 55 & 86 \\
\hline 13 & M. RIZKY JULIANSYAH & 50 & 89 \\
\hline 14 & RATNA JURIAH & 42 & 77 \\
\hline 15 & RIZKY DWI AMANDA & 43 & 65 \\
\hline 16 & SANIA NUR HALIMAH & 52 & 80 \\
\hline 17 & FAREL ANTHONY & 65 & 80 \\
\hline 18 & DEWI ATIKA NAJWA & 65 & 82 \\
\hline 19 & M. PANJI NUR YUSUF & 42 & 71 \\
\hline 20 & RISKA AGUSTINA & 75 & 92 \\
\hline & TOTAL & $\mathbf{1 0 6 9}$ & $\mathbf{1 5 9 3}$ \\
\hline
\end{tabular}

The formula as follow:

Pretest

$$
\begin{aligned}
& \text { My1 }=\frac{\sum y 1}{n} \\
& \text { My1 }=\frac{1069}{20} \\
& \text { My1 }=\mathbf{5 3 . 4 5}
\end{aligned}
$$

Post-test

$$
\begin{aligned}
& \mathrm{M}_{\mathrm{y} 2}=\frac{\sum y 2}{n} \\
& \mathrm{M}_{\mathrm{y} 2}=\frac{1593}{20} \\
& \mathrm{My} 2=\mathbf{7 9 . 6 5}
\end{aligned}
$$

Where:

$\sum=$ Total

$\mathrm{M}_{\mathrm{x} 1}=$ The mean for deviation $\mathrm{x}_{1}$ 
$\mathrm{Mx} 2=$ The mean for deviation $\mathrm{x}_{2}$

$N=$ The number of students

Score of Pre test and Post Test Experimental Class

Table 3.2 Pre and Post Test Scores for Experimental Class

\begin{tabular}{|l|l|l|l|}
\hline No & Name & Pre - test $\left(\mathrm{X}_{1}\right)$ & Post test $\left(\mathrm{X}_{2}\right)$ \\
\hline 1 & ARDYANSYAH PUTRA & 59 & 69 \\
\hline 2 & AYU ARYANTI & 61 & 95 \\
\hline 3 & DAFFA APRIYANSYAH & 45 & 81 \\
\hline 4 & ERLANGGA WAHYUDI & 45 & 79 \\
\hline 5 & FASHA ADYANSYAH & 60 & 85 \\
\hline 6 & GIBRAL ALIF & 60 & 95 \\
\hline 7 & HANIFAH TALAWAH & 60 & 80 \\
\hline 8 & IBNU WANDA & 52 & 74 \\
\hline 9 & KHAIRUNNISA & 35 & 95 \\
\hline 10 & MIFTAHUL RIZKI & 45 & 85 \\
\hline 11 & M.FAHRI & 38 & 80 \\
\hline 12 & NUR FITRI HANDAYANI & 44 & 78 \\
\hline 13 & OKTA APRIANI & 38 & 80 \\
\hline 14 & RAFA PRAYOGA & 62 & 90 \\
\hline 15 & RENDY ADRIYAN & 55 & 80 \\
\hline 16 & VINZA AULIA AZRI & 60 & 88 \\
\hline 17 & ZAHARA ANASTASYA & 65 & 95 \\
\hline 18 & ZULAIKA PRISULI & 32 & 84 \\
\hline 19 & CINDY AULIA SARI & 45 & 90 \\
\hline 20 & REHAN ATILA & 62 & 72 \\
\hline & TOTAL & $\mathbf{1 0 2 3}$ & $\mathbf{1 6 7 5}$ \\
\hline & & & \\
\hline
\end{tabular}

The formula as follow:

Pre test

$\operatorname{Mx} 1=\frac{\sum x 1}{n}$

$\mathrm{Mx} 1=\frac{1023}{20}$

$\mathrm{Mx} 1=\mathbf{5 1 . 1 5}$

Post test

$\mathrm{Mx}_{2}=\frac{\sum x 2}{n}$

$\mathrm{Mx}_{2}=\frac{1675}{20}$

$\mathrm{Mx}_{2}=83.75$

Copyright (C2021 JOEPALLT

Journal of English Pedagogy, Linguistics, Literature, and Teaching 
Where:

$\sum=$ Total

$\mathrm{M}_{\mathrm{y} 1}=$ The mean for deviation $\mathrm{y}_{1}$

My2 $=$ The mean for deviation $\mathrm{y}_{2}$

$N=$ The number of students

\section{Data Analysis}

Once the researcher obtained the average and total results of the student's pre and post test, then for the researcher to obtain the final result, the researcher used the t-test to find the difference in the average with the formula:

Table 3.3 Data of the control group $Y$ and $Y^{2}$ values

\begin{tabular}{|l|l|l|l|}
\hline No & Name & Y & $Y^{2}$ \\
\hline 1 & ADEK KURNIAWAN & 26 & 676 \\
\hline 2 & ADEN AZI ANUGRAH & 26 & 676 \\
\hline 3 & AIDIL PRASETYA & 29 & 841 \\
\hline 4 & AIRIL RAMADANI & 12 & 144 \\
\hline 5 & DAMAL RIVALDO & 26 & 676 \\
\hline 6 & FASYA AYU AZZAHRA & 28 & 784 \\
\hline 7 & FABIAN ANURAGA AKMAL & 35 & 1225 \\
\hline 8 & FAYYAZA ALFAZILA & 25 & 625 \\
\hline 9 & GILANG ANGGA KUSUMA & 38 & 1444 \\
\hline 10 & IDRIS AFFANDI & 25 & 625 \\
\hline 11 & M. ABDULLAH ZOHIR & 21 & 441 \\
\hline 12 & MAGHFIROH NABILA & 31 & 961 \\
\hline 13 & M. RIZKY JULIANSYAH & 39 & 1521 \\
\hline 14 & RATNA JURIAH & 35 & 1225 \\
\hline 15 & RIZKY DWI AMANDA & 22 & 484 \\
\hline 16 & SANIA NUR HALIMAH & 28 & 784 \\
\hline 17 & FAREL ANTHONY & 15 & 225 \\
\hline 18 & DEWI ATIKA NAJWA & 17 & 289 \\
\hline 19 & M. PANJI NUR YUSUF & 29 & 841 \\
\hline 20 & RISKA AGUSTINA & 17 & 289 \\
\hline & TOTAL & $\mathbf{5 2 4}$ & $\mathbf{1 4 7 7 6}$ \\
\hline & & & \\
\hline
\end{tabular}

$$
\begin{aligned}
\sum \mathrm{Y}^{2} & =\sum \mathrm{Y}^{2}-\frac{(y)^{2}}{n} \\
& =14776-\frac{(524)^{2}}{20} \\
& =14776-13728 \\
& =1048
\end{aligned}
$$


Table 3.4 Data of the experimental group $X$ and $X^{2}$ values

\begin{tabular}{|l|l|l|l|}
\hline No & Name & X & $X^{2}$ \\
\hline 1 & ARDYANSYAH PUTRA & 10 & 100 \\
\hline 2 & AYU ARYANTI & 34 & 1156 \\
\hline 3 & DAFFA APRIYANSYAH & 36 & 1296 \\
\hline 4 & ERLANGGA WAHYUDI & 36 & 1296 \\
\hline 5 & FASHA ADYANSYAH & 25 & 625 \\
\hline 6 & GIBRAL ALIF & 35 & 1225 \\
\hline 7 & HANIFAH TALAWAH & 20 & 400 \\
\hline 8 & IBNU WANDA & 22 & 484 \\
\hline 9 & KHAIRUNNISA & 60 & 3600 \\
\hline 10 & MIFTAHUL RIZKI & 40 & 1600 \\
\hline 11 & M.FAHRI & 42 & 1764 \\
\hline 12 & NUR FITRI HANDAYANI & 34 & 1156 \\
\hline 13 & OKTA APRIANI & 42 & 1764 \\
\hline 14 & RAFA PRAYOGA & 28 & 784 \\
\hline 15 & RENDY ADRIYAN & 25 & 625 \\
\hline 16 & VINZA AULIA AZRI & 28 & 784 \\
\hline 17 & ZAHARA ANASTASYA & 30 & 900 \\
\hline 18 & ZULAIKA PRISULI & 52 & 2704 \\
\hline 19 & CINDY AULIA SARI & 45 & 2025 \\
\hline 20 & REHAN ATILA & 10 & 100 \\
\hline & TOTAL & $\mathbf{6 5 4}$ & $\mathbf{2 4 3 8 8}$ \\
\hline & & & \\
\hline
\end{tabular}

$$
\begin{aligned}
\sum \mathrm{x}^{2} & =\sum \mathrm{x}^{2}-\frac{(x)^{2}}{n} \\
& =24388-\frac{(654)^{2}}{20} \\
& =24388-21385 \\
& =3003
\end{aligned}
$$

\section{Calculating the $T$ value:}

$\mathrm{Mx}=\mathrm{Mx} 2-\mathrm{Mx} 1$

$\mathrm{My}=\mathrm{My} 2-\mathrm{My} 1$

$$
\begin{aligned}
t & =\frac{\mathrm{M} x-\mathrm{M} y}{\sqrt{\left(\frac{\sum x^{2}+\sum y^{2}}{\mathrm{~N} x+\mathrm{N} y-2}\right)\left(\frac{1}{\mathrm{~N} x}+\frac{1}{\mathrm{~N} y}\right)}} \\
& =\frac{32.6-26.2}{\sqrt{\left(\frac{3003+1048}{40-2}\right)\left(\frac{1}{20}+\frac{1}{20}\right)}} \\
& =\frac{6.4}{\sqrt{\left(\frac{1955}{38}\right)(0.1)}}
\end{aligned}
$$




$$
\begin{aligned}
& =\frac{6.4}{\sqrt{(51.44)(0.1)}} \\
& =\frac{6.4}{\sqrt{5.144}} \\
& =\frac{6.4}{2.26} \\
& =2.831
\end{aligned}
$$

Explanation :

$\mathrm{M}=$ Average value of group results

$\mathrm{N}=$ Number of subjects

$x=$ The deviation of each of the $x_{1}$ dan $x_{2}$

$y=$ The deviation of each of the $\mathrm{y}_{1}$ dan $\mathrm{y}_{2}$

\section{Hypothesis Test}

Researchers used a parametric test using the T-test to analyze the hypothesis. After calculating all available data, the calculation obtained $t_{\text {test }}=2.831 \geq t_{\text {table }}=$ 1.685. From the results of the calculation of the $t_{\text {test }}$ value is higher than $t_{\text {table, }}$, so the conclusion is that the use of the picture and picture method has an effect on students' ability to write text descriptions.

\section{Discussion}

Based on the findings, the researchers discussed for the results of this study. In this case, the theory which state that pictures and pictures isone of the effective methods in teaching writing the descriptive text.

\section{CONCLUSIONS AND SUGGESTIONS}

\section{Conclusions}

Based on the obtained analysis results, it can be obtained that the use of pictures in picture media can give good results in writing descriptive text.Researchers found that picture and picture strategies are more successful. It can be seen from the obtained calculations that $t_{\text {test }}=2.831 \geq t_{\text {table }}=1.685$. From the calculation result of ttest value, the value of $t_{\text {test }}$ is higher than $t_{\text {table, so the }}$ conclusion is that the use of pictures and picture methods will affect the ability of students to write descriptions. Teachers can use pictures and pictures to illustrate the course being discussed, so that the explanation is more specific than the description in words.

\section{Suggestions}

1. Especially students studying in the SMP Al-Hidayah Medan area should consider using pictures to make the course on writing descriptive text easier.

2. English teachers should use picture and picture as a method in teaching the descriptive writing to make students interested and in the learning process. 
3. It is recommended that readers, especially students who are interested in the English department and writing the descriptive text, after have a certain understanding of this thesis.It will become a good example of using it for individuals or families.

4. Other researchers may consider looking at the journal in their own direction to conduct another study on the same topic.

\section{REFERENCES}

Afifah, A. N. (2019). The Effect of Gallery Walk Technique on Students' Writing Ability of Descriptive Text. Jakarta: Syarif Hidayatullah State Islamic University.

Arga, P. A. (2017). Pengaruh Model Active Learning Tipe Index Card Match Terhadap Pembelajaran Matematika Perkalian Kelas III SDN I Kebraon. Surabaya: Universitas Negeri Surabaya.

Arikunto, S. (2002). Prosedur Penelitian. Jakarta: PT Rineka Cipta.

Dewi, F. K. (2013). Penerapan Model Picture and Picture untuk Meningkatkan Keterampilan Menulis Deskripsi Pada Siswa Kelas II SDN Bringin 02 Semarang. Semarang: Universitas Negeri Semarang.

Fitriani, S. W. (2009). The Effectiveness of Using Pictures in Writing Descriptive Text to The Eight Grade Students of Junior High School (A Case Study at the Eight Grade of SMP Negeri 26 Semarang in the Academic Year of 2008-2009). Semarang: Universitas Negeri Semarang.

Fitriani, S. W. (2009). The Effectiveness of Using Pictures in Writing Descriptive Text to The Eight Grade Students of Junior High School (A Case Study at the Eight Grade of SMP Negeri 26 Semarang in the Academic Year of 2008-2009). Semarang: 2009.

Melia Sesrica, Jismulatif, Afrianto. (2016/2017). The Effect of Using Pictures in Teaching Writing Descriptive text For The Second Year Students of SMPN 1 Siak. Riau: Riau University.

Nova, M. (2020, July 15). Mastarita nova Blog. From http://mastaritanova.blogspot.com/2012/09/penelitian-kuantitatif.html

Novita, V. T. (2014). The Effectiveness Of Teaching Writing Through Picture Series To Grade VIII Students Of SMP N 3 Sleman. Yogyakarta: Universitas Negeri Yogyakarta.

Puspitaloka, N. (2016). The Effect of Picture Series Toward Students' Descriptive Writing Skill. Karawang : : Universitas Singaperbangsa Karawang.

Raguyamanan. (2020, July 13). Definition of Recount, Report, Narrative, Descriptive and Procedure Text. From Raguyamanan: https://rugayamanan.wordpress.com/2012/12/08/definition-of-recountreport-narrative-descriptive-and-procedure-text/

Sa'diyah, H. (2011). Improving Students' Ability in Writing Descriptive Text Through Picture Series-Aided Learning Strategy. Lamongan: Malaysian 
English Language Teaching Association.

Siahaan, J. (2013). An Analysis Of Students' Ability And Difficulties In Writing Descriptive Text. Jakarta: Indonesia University.

Soejatmiko and Taloko. (2003). Teaching Writing Using Electronic Portfolio in the Multimedia Lab at Widya Mandala Surabaya Catholic University. Surabaya: Widya Mandala Surabaya Catholic University.

Solechah, Z. J. (2017). The Effectiveness of Teaching Writing In Descriptive Text By Using Edmodo. Surakarta: State Islamic Institution of Surakarta. 